\title{
DISCONTINUOUS SPLENOGONADAL FUSION IN A PATIENT WITH LEFT TESTICULAR MASS
}

\author{
Sushentsev N. 1, Calleja R. 2, Warren A. 3, Livni N. 3, Barrett T. 1,4,5
}

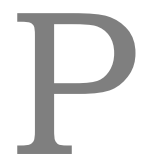

urpose. Splenogonadal fusion (SGF) is a benign congenital anomaly that occurs predominantly in males and presents clinically as a testicular lump which is comprised of normal splenic tissue. There are two types of SGF: continuous and discontinuous. In continuous SGF, a fibrous band of splenic tissue is found between the spleen and testis and can be easily recognized on imaging studies. Conversely, diagnosis of discontinuous SGF is far from straightforward: if misdiagnosed, it leads to unnecessary orchiectomy in about a third of reported cases.

We report a case of discontinuous SGF which was diagnosed postoperatively in a patient with left testicular mass. We also provide a comprehensive review of imaging features and differential diagnosis of discontinuous SGF.

Keywords: splenogonadal fusion, testicular mass, spleen, testis, CT, US

Corresponding author: Sushentsev N., e-mail: sushentsev.na@1msmu.ru

For citation: Sushentsev N., Calleja R., Warren A., Livni N., Barrett T. Discontinuous splenogonadal fusion in a patient with left testicular mass. REJR 2017; 7 (4):156-160. DOI:10.21569/2222-7415-2017-7-4-156-160.
Received:
15.11.17
Accepted:
29.11.17

\section{ПРЕРЫВНОЕ СПАЕНОГОНААНОЕ САИЯНИЕ У ПАЦИЕНТА С ОБРАЗОВАНИЕМ АЕВОГО ЯИЧКА}

\author{
Сушенцев Н. ', Кальеха Р. 2, Уоррен Э.3, Аивни Н. ${ }^{3}$, Барретт Т. 1,4,5
}

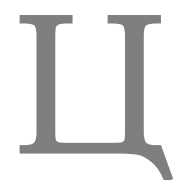

емь исследования. Спленогонадное слияние (СГС) является доброкачественной врожденной аномалией, наблюдающейся преимущественно у мужчин и имеющей клиническую картину образования яичка, состоящего из нормальной ткани селезенки. Существует два типа СГС: непрерывное и прерывное. При непрерывном СГС фиброзный тяж, остающийся между селезенкой и яичком, мегко определяется на мучевых исследованиях. Напротив, диагностика прерывного СГС не столь очевидна; ошибочная диагностика ведет к выполнению необязательной орхиэктомии в одной трети случаев.

В данной работе представмен случай прерывного СГС, которое бымо диагностировано после проведения оперативного вмешательства у пациента с образованием мевого яичка. На основании анализа митературы в работе также приведены мучевые характеристики и основы дифференциального диагноза прерывного СГС.

Ключевые слова: спленогонадное слияние, образование яичка, селезенка, яичко, КТ, УЗИ.

Контактный автор: Sushentsev N., e-mail: sushentsev.na@1msmu.ru

Для иитирования: Сушениев Н., Кальеха Р., Уоррен Э., Аивни Н., Барретт Т. Прерывное спленогонадное слияние у пациента с образованием левого яичка. REJR 2017; 7 (4):156-160. DOI:10.21569/2222-7415-2017-7-4-156-160.

1 - ФГАОУ ВО Первый МГМУ им. И.М. Сеченова Минздрава России. Москва, Россия. 2 - Госпиталь королевы Елизаветы, Кингс Аинн, Великобритания.

3 - Госпиталь Адденбрукс, Кембридж, Великобритания. 4 - Госпиталь Адденбрукс, Кембридж, Вемикобритания. 5 - Госпиталь Адденбрукс и Кембриджский

Университет,

Кембридж, Великобритания.

\section{Статья получена: $\quad$ 15.11.17 $\quad$ Статья принята: $\quad 29.11 .17$}




\section{RUSSIAN ELECTRONIC JOURNAL OF RADIOLOGY}

I n developed countries, testicular cancer (TC) is the most commonly diagnosed male malignancy in the age group $15-44[1,2]$. In 2015 , Fitzmaurice et al. revealed a $40 \%$ increase in TC incidence since 2005 [3]. The same study shows that mortality of TC remains relatively low and accounts for 9 per 10,000 which is due to high treatment efficacy of timely diagnosed disease. However, misdiagnoses of benign testicular lesions are not rare and can lead to unnecessary orchiectomy procedures. Definitive preoperative diagnosis can be obtained by either percutaneous or open testicular biopsy. Although the percutaneous approach can be performed on an outpatient basis and requires only local anaesthesia, there is a risk of tumour seeding due to presumed scrotal violation [4]. Open testicular biopsy is invasive and requires theatre time, general anaesthesia and immediate histopathological analysis of a suspicious lesion [5]. Hence, management of patients with TC mainly relies on clinical, laboratory and imaging findings. Radiological assessment of patients with suspected TC includes testicular ultrasound (US) with Doppler imaging and computed tomography (CT) of chest, abdomen and pelvis. Imaging is important in differentiating TC from benign condition including focal infarction, haematoma, infection, epidermoid cysts, or nonprimary tumours, such as lymphoma, metastasis, adrenal rest tumours, etc. [6] In this report, we describe a case of discontinuous splenogonadal fusion (SGF) which was diagnosed postoperatively in a patient with left testicular mass.

\section{Case report.}

A 32-year-old male with a history of left testicular lump which he noticed during selfexamination was referred for testicular ultrasound (US). The patient had no history of cryptorchidism or other congenital anomalies and was otherwise healthy. On physical exam, a small lump was found in the upper pole of the left testis. The left side of the scrotum was moderately swollen.

The patient was referred for an urgent testicular ultrasound and bloods sent for tumor markers. Serum alpha-fetoprotein was $3.2 \mathrm{kU} / \mathrm{L}$ (normal range $<7 \mathrm{kU} / \mathrm{L}$ ), beta subunit of human chorionic gonadotropin was $1.2 \mathrm{U} / \mathrm{L}$ (normal range $0-4 \mathrm{U} / \mathrm{L}$ ) and lactate dehydrogenase was $153 \mathrm{U} / \mathrm{L}$ (normal range $120-246 \mathrm{U} / \mathrm{L}$ ). Left testicular US revealed a $16 \times 13 \mathrm{~mm}$ intra-testicular appearing solid lesion at the upper pole, which was highly vascular on Doppler imaging (Fig. 1); the contralateral testis had normal appearance. A working diagnosis of primary testicular tumor was made. Subsequent staging CT of chest, abdomen and pelvis showed no sign of distant spread.

The patient underwent left inguinal radical orchiectomy. The histology report described the lesion as an intratesticular nodule of splenic tissue with no evidence of malignancy (Fig. 2), with the final diagnosis of discontinuous SGF being made.

\section{Discussion.}

Although SGF was first reported in literature by Bostroem in 1883, it was Putschar and Manion who first introduced its classification in 1956 [7, 8]. Around 200 cases of SGF have been described in the literature since then [9]. SGF is a benign congenital anomaly that arises during the 5th to 8th week of gestation due to a fusion between the surface of the developing genital ridge and the splenic anlage. There are two types of SGF: continuous and discontinuous; both types are reported to occur with the same frequency [10]. In $98 \%$ of cases SGF has been reported on the left side and male-to-female ratio is $15: 1$ [11, 12]. Preoperative misdiagnosis leads to unnecessary orchiectomy in about a third of reported cases [13].

Although there are several anecdotal reports of malignancy associated with SGF, it is generally considered a benign anomaly [14-16]. It is widely accepted that once an accurate pre- or intraoperative diagnosis is made, surgery is not needed in the absence of significant complications [17]. In patients with continuous SGF who undergo orchiopexy, the splenic band can be easily separated from the testicular vessels and removed alongside with the splenic tissue affecting the testis [18-20].

The most common modes of presentation for both types of SGF are left hemiscrotal swelling, left inguinal hernia and left undescended testis [10]. Continuous SGF is diagnosed when a fibrous band of splenic tissue is found between the spleen and testis and can be unmistakably recognized on imaging studies [19, 21-23]. Continuous SGF is often associated with other anomalies such as cryptorchidism and limb defects [24]. However, diagnosis of discontinuous SGF is far from straightforward.

On testicular US, discontinuous SGF often looks like solid, homo- or heterogeneous, oval, separate soft tissue mass located in the upper pole of the testis. Color Doppler may show a central feeding vessel that branches outwards in a centrifugal manner (our case shows this in Fig. 1B). Intratesticular location of the mass is another feature which is often reported as consistent with primary TC and therefore absence of a "claw" sign can point to an extra-testicular origin $[25,26]$. Both CT and magnetic resonance (MR) scans is valuable in delineating a soft tissue mass, distinguishing between testicular and extra-testicular 


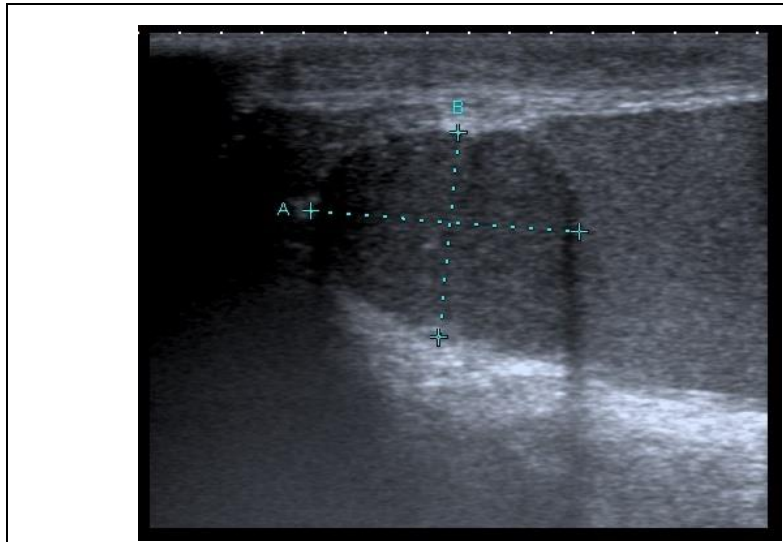

Pис. 1 a (Fig. 1 a)

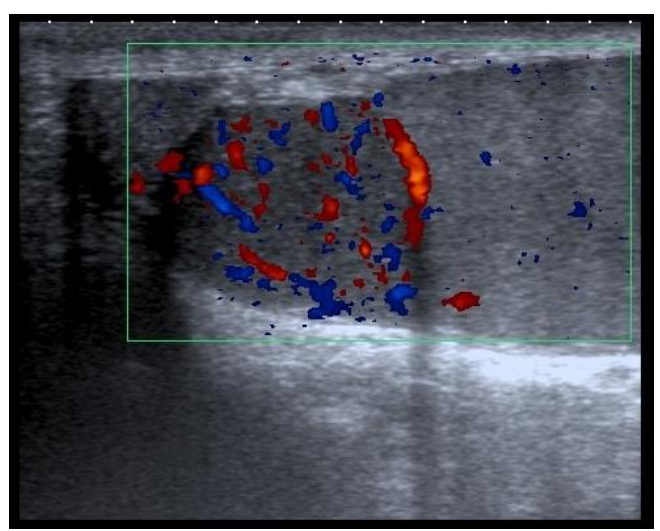

Рис. 16 (Fig. 1 в)

Fig. 1. Left testicular US (a) with Doppler imaging (b). 32-year-old male with splenogonadal fusion.

Homogeneous, hypoechoic, apparently intratesticular, highly-vascular soft-tissue mass measuring 16 x 13 mm and located in the upper pole of the testis.

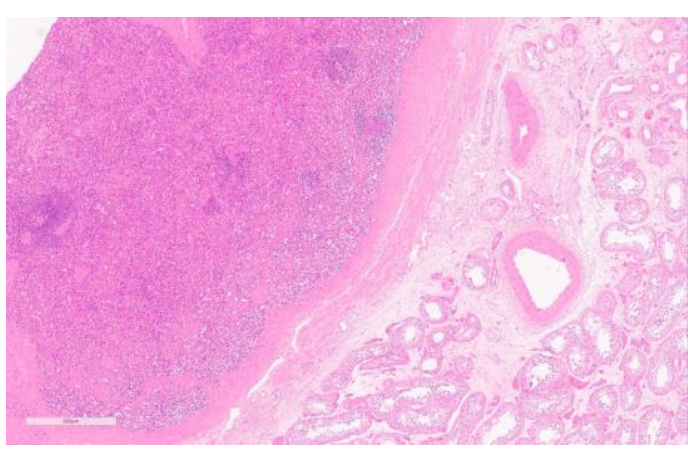

Puc. 2 a (Fig. 2 a)

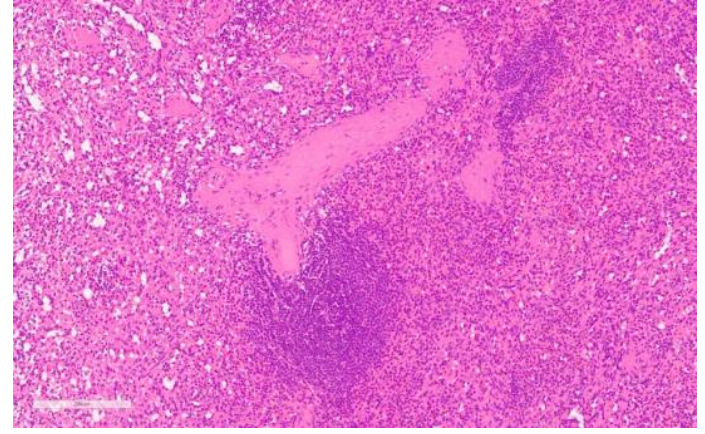

Puc. 26 (Fig. 2 в)

Fig. 2. Low (a) and medium (a) magnification haematoxylin and eosin stained section of the intratesticular splenic tissue.

32-year-old male with discontinuous splenogonadal fusion. Low magnification section (a) showing splenic tissue with a surrounding fibrous capsule (left) clearly demarcated from the normal testicular tissue (right). Medium magnification section (b) showing the typical architecture of normal spleen, with 'white pulp' lymphoid tissue (centre) surrounded by the blood filled sinuses of the 'red pulp'.

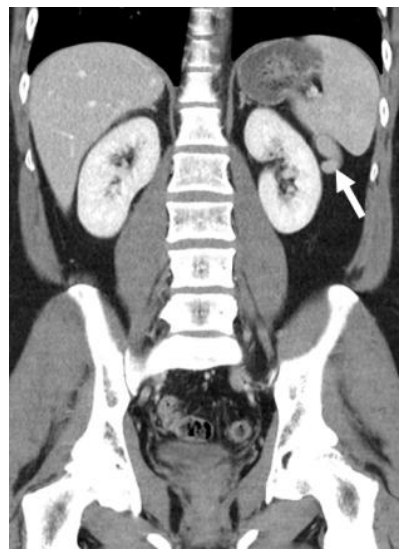

Рис. 3 a (Fig. 3 a)

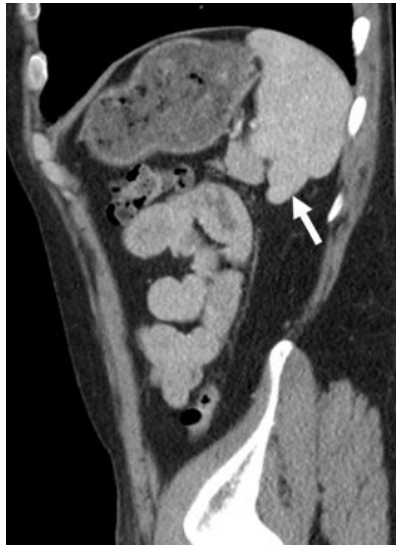

Рис. 36 (Fig. 3 в)

\section{Fig. 3. $\mathrm{CT}$ of the chest and abdomen. 32-year-old male with splenogonadal fusion.}

Coronal (a) and sagittal (b) reformatted CT demonstrate tail-shaped extension of the spleen which might represent a residual splenic cord which had once connected the spleen with yet undescended testis. 
pathologic processes and determining solid or cystic nature of the lesions as well as showing SGF lesions to have a characteristic splenic enhancement pattern [27]. Single-photon emission computed tomography (SPECT) using technetium$99 \mathrm{~m}$ labelled heat-denatured red blood cells or sulfur colloid is a gold standard in diagnosing ectopic splenic tissue and thus can be used in differential diagnosis of discontinuous SGF [28, 29].

The differential diagnosis of discontinuous SGF is indeed far from straightforward. The majority of orchiectomy procedures performed in patients with discontinuous SGF are due to high suspicion of testicular malignancy. TC can be bilateral and multifocal, and tumors may have foci of calcification and cystic spaces. Blood flow pattern is often irregular and depends on the tumor histological subtype [6]. In primary testicular lymphoma, tumors can be multifocal and bilateral; hypervascularity of the testis and epididymis is frequently noted on color Doppler [30]. Epididymitis has an acute onset and presents with fever and elevated inflammatory markers. On testicular US, inflammation is limited to the epididymis; reactive hydrocele and scrotal wall thickening can be present. Color Doppler and contrast-enhanced $\mathrm{CT}$ reveal increased blood flow in the spermatic cord vessel [31, 32]. Intratesticular hematomas present as iso- or hyperechoic lesions in the traumatized testis with little or no blood flow detected on Doppler imaging [33]. Segmental testicular infarction also shows reduced or absent blood flow and typically looks like wedge-shaped or rounded hypoechoic lesion [34]. Adrenal rests are usually multiple, bilateral and eccentrically located lesions in the mediastinum testis; diffuse, irregular enlargement of both adrenal glands seen on CT is typical [35]. Testicular epidermoid cysts have characteristic lamellated "onion skin" ap- pearance with alternating hyper- and hypoechoic rings and are non-vascular [36].

In our patient, CT of chest, abdomen and pelvis revealed a tail-shaped extension of the spleen which was prospectively regarded as normal anatomical variant (Fig. 3). This extension likely represents a residual splenic cord which detached from the subsequent successfully descended left testis. To our knowledge, this is the first case report to describe such a finding and leads us to postulate that the case has additional features of continuous SGF and may suggest that both types of SGF indeed share a common aetiology. This issue was addressed by Le Roux and Heddle in 2000 who then argued that discontinuous SGF is no more than a rare variant of an accessory spleen [37]. Thus, we propose that any anatomical abnormalities of the spleen in patients with left testicular masses should raise suspicion of discontinuous SGF.

In summary, preoperative prospective diagnosis of discontinuous SGF is far from straightforward and is not usually made unless the clinicians have encountered previously and are aware of this condition. Although SGF is rare, it is of great importance for clinicians to be aware of the diagnosis as the affected testis can eventually be spared. All patients with normal tumor and inflammatory markers, left-sided soft-tissue testicular lesion with spleen-like Doppler blood flow and any splenic anomaly on CT should be referred to SPECT or open biopsy to rule out a diagnosis of discontinuous SGF.

\section{Source of financing and conflict of inter-} ests.

Authors of this article confirmed lack of financial support of a research and conflict of interests about which it is necessary to report.

\section{References:}

1. Trabert B., Chen J., Devesa S.S., Bray F., McGlynn K.A. International patterns and trends in testicular cancer incidence, overall and by histologic subtype, 1973-2007. Andrology. 2015; 3 (1): 4-12.

2. Ghazarian A.A., Trabert B., Devesa S.S., McGlynn K.A. Recent trends in the incidence of testicular germ cell tumors in the United States. Andrology. 2015; 3 (1): 13-8.

3. Fitzmaurice C., Allen C., Barber R.M., Barregard L., Bhutta Z.A., Brenner H., et al. Global, Regional, and National Cancer Incidence, Mortality, Years of Life Lost, Years Lived With Disability, and Disability-Adjusted Life-years for 32 Cancer Groups, 1990 to 2015: A Systematic Analysis for the Global Burden of Disease Study. JAMA Oncol. 2017; 3 (4): 524-48.

4. Corby H.M., Lynch T.H., Fitzpatrick J.M., Smith J.M. Inguinal lymph node metastases from a testicular tumour. $\mathrm{Br} J$ Urol. 1996; 77 (6): 923-4.

5. Shaida N., Berman L.H. Percutaneous testicular biopsy for indeterminate testicular lesions. Br J Radiol. 2012; 85 Spec No

1: $\$ 54-8$.

6. Moreno C.C., Small W.C., Camacho J.C., Master V., Kokabi N., Lewis M., et al. Testicular Tumors: What Radiologists Need to Know-Differential Diagnosis, Staging, and Management. http://dxdoiorg/101148/rg352140097. 2015.

7. Bostroem E. Demonstration eines Praparates yon Verwaehsung der Milz mit dem linken Hoden. Gesellsehaft deutseher Naturforseher und Aerzte, Verhandlungen der 56 Versammlung,

Freiburg, 1883. 149 p.

8. Putschar W.G.C. Splenic-gonadal fusion. In: Manion, WC, editors. Am J Pathol1956. 15 .

9. Jayasundara J.A., Vithana V.H., Lamahewage A.K. A case of continuous-type splenogonadal fusion. Singapore Med J. 2013; 54 (6): e123-4.

10. Carragher A.M. One hundred years of splenogonadal fusion. Urology. 1990; 35 (6): 471-5.

11. Varma D.R., Sirineni G.R., Rao M.V., Pottala K.M., Mallipudi 


\section{RUSSIAN ELECTRONIC JOURNAL OF RADIOLOGY}

B.V. Sonographic and CT features of splenogonadal fusion. Pediatr Radiol. 2007; 37 (9): 916-9.

12. Andrews R.W., Copeland D.D., Fried F.A. Splenogonadal fusion. J Urol. 1985; 133 (6): 1052-3.

13. Karaman M.I., Gonzales E.T., Jr. Splenogonadal fusion: report of 2 cases and review of the literature. J Urol. 1996; 155 (1): 309-11.

14. Imperial S.L., Sidhu J.S. Nonseminomatous germ cell tumor arising in splenogonadal fusion. Arch Pathol Lab Med. 2002; 126 (10): 1222-5.

15. Falkowski W.S., Carter M.F. Splenogonadal fusion associated with an anaplastic seminoma. J Urol. 1980; 124 (4): 562-4.

16. Lopes R.I., de Medeiros M.T., Arap M.A., Cocuzza M., Srougi $M$., Hallak J. Splenogonadal fusion and testicular cancer: case report and review of the literature. Einstein (Sao Paulo). 2012; 10 (1): $92-5$.

17. Verga G., Parigi G.B. Splenic gonadal fusion: a plea for conservative surgery. Urology. 35. United States1990. $99 \mathrm{p}$.

18. Braga L.H., Braga M.M., Dias M.A. Laparoscopic diagnosis and treatment of splenogonadal fusion associated with intraabdominal cryptorchidism in a child. Pediatr Surg Int. 1999; 15 (7): 465-6.

19. Li Y.H. Preoperative detection of splenogonadal fusion by CT. Surg Radiol Anat. 2009; 31 (9): 733-5.

20. Huang G., Huang Y., Zeng L., Yuan M., Wu.Y., Huang L. Continuous-type splenogonadal fusion: A case report. Exp Ther Med. 132017. P. 2019-21.

21. Nimkin K., Kleinman P.K., Chappell J.S. Abdominal ultrasonography of splenogonadal fusion. J Ultrasound Med. 2000; 19 (5): 345-7.

22. Stewart V.R., Sellars M.E., Somers S., Muir G.H., Sidhu P.S. Splenogonadal fusion: B-mode and color Doppler sonographic appearances. J Ultrasound Med. 2004; 23 (8) :1087-90.

23. Jakkani R., Alhajri F.A., Alteriki A., Almuteri M.F., Athyal R.P., Hashem K.Z. Discontinuous splenogonadal fusion diagnosed on computed tomography. Indian $J$ Radiol Imaging. 262016. P. 506-9.

24. Cortes D., Thorup J.M., Visfeldt J. The pathogenesis of cryptorchidism and splenogonadal fusion: a new hypothesis. $\mathrm{Br} J$ Urol. 1996; 77 (2): 285-90.
25. Uglialoro A.D., Goltzman M.E., Niazi M., Lehman D., Silletti J., Bjurlin M.A. Splenogonadal Fusion Presenting as an Asymptomatic Testicular Mass. Urology. 2016; 97: 1-4.

26. Kocher N.J., Tomaszewski J.J., Parsons R.B., Cronson B.R., Altman H., Kutikov A., et al. Splenogonadal fusion: a rare etiology of solid testicular mass. Urology. 2014; 83 (1): e1-2.

27. Joda A., Aziz A. Spleno-gonadal fusion as a cause of left undescended testis: Case report \& review of literature - Journal of Pediatric Surgery Case Reports. 2017.

28. Steinmetz A.P., Rappaport A., Nikolov G., Priel I.E., Chamovitz D.L., Dolev E. Splenogonadal fusion diagnosed by spleen scintigraphy. J Nucl Med. 1997; 38 (7): 1153-5.

29. Schonlau D., Barker D., Hall N. SPECT/CT imaging of a retroperitoneal nodule in a patient with history of infiltrating renal urothelial carcinoma. J Radiol Case Rep. 32009. P. 18-21.

30. Kim J., Abu-Yousef M. Testicular lymphoma. Ultrasound $Q$. 2013; 29 (3): 247-8.

31. Smith R.P., Tracy C.R., Kavoussi P.K., Witmer M.T., Costabile R.A. The impact of color Doppler ultrasound on treatment patterns of epididymitis in a university-based healthcare system. Indian J Urol. 292013. P. 22-6.

32. Gupta S.A., Horowitz J.M., Bhalani S.M., Chalian H., Hammond N.A., Berggruen S., et al. Asymmetric spermatic cord vessel enhancement on CT: a sign of epididymitis or testicular neoplasm. Abdom Imaging. 2014; 39 (5): 1014-20.

33. Bhatt S., Dogra V.S. Role of US in testicular and scrotal trauma. Radiographics. 2008; 28 (6): 1617-29.

34. Aquino M., Nghiem H., Jafri S.Z., Schwartz J., Malhotra R., Amin M. Segmental testicular infarction: sonographic findings and pathologic correlation. J Ultrasound Med. 2013; 32 (2): 36572.

35. Olpin J.D., Witt B. Testicular Adrenal Rest Tumors in a Patient with Congenital Adrenal Hyperplasia. J Radiol Case Rep. 82014. P. 46-52.

36. Loya A.G., Said J.W., Grant E.G. Epidermoid cyst of the testis: radiologic-pathologic correlation. Radiographics. 2004; 24 Suppl 1: S243-6.

37. Le Roux P.J., Heddle R.M. Splenogonadal fusion: is the accepted classification system accurate? BJU Int. 2000; 85 (1): 114-5. 